\title{
Cultural and Educational Values in Pantun Seserahan at Lubuk Rukam Village, Peninjauan District, OKU Regency
}

\author{
Friska Andriyani $^{\left.1^{*}\right)}$, Ratu Wardarita ${ }^{2}$, Missriani $^{2}$
}

\author{
${ }^{1}$ SMP Negeri 29 OKU \\ ${ }^{2}$ Universitas PGRI Palembang \\ *Corresponding author.Email: friskaandriyani83@gmail.com
}

\begin{abstract}
This study aims to identify and describe the cultural, educational and dominant values found in the pantun seserahan in Lubuk Rukam Village, Peninjauan District, OKU Regency. This research is qualitative research with a descriptive approach. The data collection techniques are observation, interview, and documentation. Based on the results of this study, in general, pantun seserahan in Lubuk Rukam Village, Peninjauan District, OKU Regency aims to describe the cultural and educational values that exist in the society. So, it can be concluded that pantun is one of the ways than can be used to educate the young generation in certain society. But, every human behavior and way of thinking cannot be said to be a culture and tradition, except after being practiced for a long time and passed down from generation to generation.
\end{abstract}

Keywords: Culture, Education, Pantun

\section{INTRODUCTION}

Indonesian literature is a language element found in Indonesian. Literature is a beautiful or well-ordered language, and its presentation style is attractive so that it impresses the reader's heart. Indonesian literature is divided into two, namely old literature and new/ modern literature [1].

Literature is a loan word from Sanskrit literature, which means "text that contains instructions" or "guidelines", from the meaning of the word "instruction" or "teaching". In the Indonesian word, it is used to refer to "literature" or some kinds of writing which have a certain meaning or beauty. Besides, in the literary sense, literature can be divided into written literature or oral literature. The literature is used as a vehicle for expressing certain experiences or thoughts.

Laelasari explains that old literary works are works produced by writers in ancient times [2]. Old literary works are in the form of old prose and old poetry. Literature is an oral literary work that has various characteristics or superior writing such as originality, artistry, beauty in content, and expression.

Generally, old literature based on its content is divided into 4 (four) types: (1) epic is an essay that describes objectively without participating in the author's thoughts and feelings; (2) lyrics, is an essay containing the outpouring of feelings from the author subjective; (3) didactic is literary work containing moral, religious, etiquette, or other messages; and (4) dramatic is literary work that contain an event that is depicted excessively [3].

Nursito explains that oral literature belongs to old literature [4]. The general characteristics of the old literature are: (1) the old literature is static in line with the conservative and traditional attitudes of society, (2) the old society prioritizes cooperative life. Therefore, old literature is the emanation of society as common property. That is why the poets do not want to highlight their name and announce the work to the public, because of the very rapid development of the writing tradition.

These literatures sometime also in oral form. There are several special things about oral literature. It gives the influence on Indonesian literature. So that, Indonesian society faced two cultural phenomena that are side by side and intersect (in terms of literature), namely oral-traditional-tribal culture and writtenmodern-national culture.

According to Hutomo, oral literature is literature that includes literary expressions of the citizens of a 
culture that are spread and passed down orally [5]. So, all cultures that are spoken orally and passed down by oral method to the generation are included in the study of oral literature, for example, folk tales, folk puzzles, folk dramas, poetry, gurindam, and so on. In Indonesia, the collection of folklore, folk poetry, and folk puzzles was carried out in the 19th century (1850-1900) by Christian and European religious publishers.

\subsection{Pantun}

Pantun is first appeared in Malay history and popular contemporary saga and was inserted into poetry such as Ken Tambuhan. Parik which means 'pari', is the proverb in Pantun that is considered a form of karma (punishment) from the Javanese word. This meaning is also close to seloka (parable) which comes from India. The word pantun comes from the root word tun, which is found in various Indonesian languages. For example in Tagalog, there is a word 'tonton' which means to speak according to certain rules; in ancient Javanese, a word 'tuntun' which means string or a word 'atuntun' which means orderly, and a word 'matuntun' which means leading; in the Toba language there is also a word pantun which means politeness, honor.

According to Effendi, pantun is a work of fiction that is built through various elements of the beauty of vocabulary arrangement, these elements are deliberately combined by the author and made similar to the real world complete with events in it so that it looks like there and happens [6]. Furthermore, Rani explains that the characteristics of the pantun include: (1) it consists of four lines; (2) each line consists of 9 to 10 syllables; (3) The first two lines are called sampiran (opening) and the next two lines contain the intention of the assistant. This part is called the contents of pantun [7].

According to Kaswan and Rita pantun is a type of old Malay poetry that verse consists of four lines and rhymes with $a-b-a-b$ form [8]. The first and second lines are sampiran (opening), while the third and fourth lines are content. Sampiran (opening) does not contain the intention, but only taking the rhymes. So, in making pantun, the content must be the first point to be created than sampiran (opening).

According to Wardarita, pantun can be classified into folk poetry, because in society it turns out that pantun occupies a very broad life, has a very strong and evenly distributed function throughout Indonesia [9]. Almost all regions in the archipelago have a tradition of chanting.

Cultural values are values that are agreed upon by all members of society, ethnicity, or nation. Whereas what is meant by a cultural value system is the order of all the values held by a group, ethnicity, or nation based on the degree of importance of these values. Individual value systems can be different but can also be the same as cultural value systems. The cultural value system of a nation will be different from other nations even though there can be 1 (one) or 2 (two) values of the same degree. This difference is caused by several factors, including the history of each nation and country, geographical conditions, the political system, the dominant religion, and the educational level of its citizens.

The cultural values arise from problems that exist in the community. The culture is a way of life that develops, and is shared by a group of people, and is passed down from generation to generation. The culture is formed from an element, namely religious systems, politics, customs, language, and works of art. The culture is also a comprehensive pattern of life that is complex, abstract, and broad and many aspects of culture determine communicative behavior. The culture is a complex whole, which contains science, belief, art, morals, law, customs, and other abilities, as well as habits acquired by humans as members of society, the elements of behavior formation are supported and passed on by members of society.

When it is linked to cultural and educational values, it is very closely related to the social order, because cultural values themselves contain elements of education. In this context, it can be seen that the relationship between education and cultural traditions and the personality of society, no matter how simple the community is. It can be seen that tradition as a cultural content is always preserved in every society, from generation to generation. This relationship, of course, will only be possible if the supporters of this value can write it down to their younger generations as the next generation.

\subsection{Types of Pantun}

According to Effendi, pantun can be divided according to their type and content, namely as follows [7]:

1. Pantun for kids

Based on the contents, pantun for kids can be divided into (1) joyous pantun, (2) mourning pantun, (3) humorous pantun.

2. Pantun for young people

Based on its contents, pantun for young people can be divided into (1) pantun for trade of fate (2) pantun for introductions, (3) pantun for compassion, (4) pantun for divorce.

3. Pantun for parents

Based on its contents, pantun for parents can be divided into (1) advice pantun, (2) traditional pantun, (3) religious pantun.

\subsection{Characteristics of Pantun}

According to Sugiarto, a verse of poetry is called a pantun, of course, it must fulfill the characteristics of a pantun. Here are the characteristics of pantun [10]: 
1. Each verse of the pantun consists of four lines

2. Each line of the pantun consists of 8-12 syllables

3. Pantun has the ending rhyme a-b-a-b

4. Each verse of pantun has sampiran (opening) and contents.

Rani says that the characteristics of the pantun are as follows [11]:

1. Consists of four lines.

2. Each line consists of 9-10 syllables.

3. The first two lines are called sampiran (opening) and the next two lines contain the meaning. This part is called the contents of the pantun.

4. Pantun emphasizes the ending rhyme. The rhyme formula is called the alphabet / ab-ab /. That is, the ending sound of the first line is the same as the ending sound of the third line and the second line is the same as the fourth line.

\subsection{Structure of the Pantun}

According to Alisyahbana, two structures form of a pantun, including the following: (1) sampiran (opening) [12]. The location of the sampiran (opening) in a pantun is usually in the first and second rows. Sampiran (opening) is not related to the contents of the pantun; (2) the content of pantun is in the third and fourth rows. This part of the content is the purpose of the pantun itself. The function of sampiran (opening) is to prepare rhymes and rhythms so that the listeners can easily understand the contents of the rhymes. This can be understood because basically, pantun is oral literature. The rhyme and rhythm patterns in a pantun explicitly emphasize the orality of the pantun in earlier Malay culture.

According to Sadikin, pantun is not just a literary work that is recorded, because in various regions in the archipelago [3]. Pantun can become a performing art in certain forms. Pantun as an oral tradition is then strengthened by the rules when the pantun becomes a literary work in written form with a rhyme structure in the form of sampiran and content.

Based on those explanations, this study is concerning on the values that exist in the pantun seserahan in Lubuk Rukam village, Peninjauan District, OKU Regency.

\section{METHODS}

\subsubsection{Qualitative Research Methods}

The research design used in this research is a descriptive qualitative method. According to Nazir in Prastowo, the descriptive method is a method used to examine the status of a group of people, an object, a set of conditions, a system of thought, or a class of events in the present [13]. According to Sukmadinata, qualitative research is research to describe and analyze phenomena, events, social activities, beliefs, perceptions, thoughts individually or in groups [14]. The qualitative method produce descriptive data in the form of written or spoken words from people and observed behavior. The result data are in the form of words, pictures, and human behavior. According to Endraswara, qualitative research is a study of empirical (cultural) phenomena in the field. Qualitative research is a multi-method study area that focuses on interpretation and naturalistic approaches to a problem. This study will cover various things which include collecting field data.

\subsubsection{Data Collection Techniques}

Data collection techniques in this study include the following:

1. Observation

Observation is used to know pantun seserahan in the society.

2. Interview

According to Sugiyono, an interview is data taken face to face with the respondents to obtain the required data or information [15]."

3. Documentation

The documentation used for data collection in this study is in the form of an interview. Also, photographs of documentation during the wedding ceremony in Lubuk Rukam village, Peninjauan District, OKU Regency. The pantun sheet used when the wedding custom was made, photos of community leaders as information, and other supporting documentation to complement the research data.

\subsubsection{Data Analysis Techniques}

Analyze the cultural and educational values that exist in each verse of the offering pantun in Lubuk Rukam Village, Peninjauan District, OKU Regency by sorting out the existing pantun offerings related to cultural and educational values.

The informants in this study are as follows:

1. A traditional figure in Lubuk Rukam village, Peninjauan District, OKU Regency is a person who is knowledgeable and understands the traditional marriage of Lubuk Rukam village;

2. The elders of the customs of Lubuk Rukam village, Peninjauan District, OKU Regency, namely the person who regulates the process of implementing the traditional marriage in Lubuk Rukam village.

3. The family or parents of the two prospective brides, residents, or ordinary people who are in the area of the bridal house 


\section{RESULTS AND DISCUSSION}

The following is an explanation of cultural values in pantun seserahan in Lubuk Rukam Village, Penininjaun District, OKU Regency as follows.

\subsection{Cultural Values in Pantun Seserahan in Lubuk Rukam Village, Peninjauan District, OKU Regency.}

The cultural values in pantun seserahan in Lubuk Rukam village, Penininjaun District, OKU Regency, can be seen in the following pantun:

\section{Tekejut bawa batang \\ Dibawa batang tempedak \\ Halatekejut kami datang \\ Kami datang ade kendak}

This pantun has meant that the man's family comes to the woman's house to have a purpose and will. At first, the male accompaniment entered the woman's house with some gifts carried by the male ladies-in-waiting young men. These gifts consist of cosmetics, clothing, food and fruits, dowry, and money that had been previously determined as the nominal amount of money. All of them were packaged in a unique and attractive container.

After entering the woman's house, the male group was invited to sit down, and then the male and female delegates shook hands. Then, the male delegation gave a few words as an introduction. After that, the male delegation mentioned one by one the gifts and then also hand over the gifts to the female. Thus, the pantun seserahan described above can be said as cultural values in Lubuk Rukam village, Peninjauan District, OKU Regency.

The cultural values in the pantun seserahan in Lubuk Rukam Village, Peninjauan District, OKU Regency are further explained as follows:

\section{Bekerite number pance \\ Tesandah ke batang bangka \\ Tutup kate tutup cerite \\ Kite lanjutkan akad nikah}

Based on the description of the pantun above, it can be said this pantun has the meaning of cultural values in the community in Lubuk Rukam, Peninjauan District, OKU Regency. In the fourth line, Kite lanjutkan akad nikah that is mean the marriage can be continued. The meaning of cultural values in the fourth line, it is explained that the cultural culture of the people of Lubuk Rukam Village, Peninjauan District, OKU Regency do not want to be wordy. It goes straight to the core of the goal.

This is also explained in the Islamic cultural order, which is described in the Qur'an Alam Nasyrah (94: 7) which means after finishing work, do something else seriously. The structure of the community in Lubuk Rukam Village, Peninjauan District, OKU Regency, was reflected in everyday life where the people of Lubuk Rukam Village, Peninjauan District, OKU Regency always want to fast and after that do other things.

Also, the meaning is the surrender of village communities in Lubuk Rukam, Peninjauan District, OKU Regency is according to the culture and customs aim to create order. A society that fulfills the requirements of security and justice for each of its members or creates harmony among intellectuals who have different understandings or opinions. The customs bring good and eliminate bad; remove the cloud and clear.

Based on a review of the meaning of cultural values in the pantun that was delivered by the people of Lubuk Rukam Village, Peninjauan District, OKU Regency, it can be understood that every human behavior and way of thinking cannot be said to be a culture and tradition, except after being practiced for a long time and passed down from generation to generation.

There are times when the acceptance of practice is strengthened by customary law, so that anyone who violates it, especially if it is done deliberately, will be subject to social sanctions. Even though it only relates to habits or prevalence, the traditional custom plays a role in shaping the tradition of cultural values. In a simple sense, cultural values are the old way people do things in all aspects of life.

The cultural values in the pantun that was created by the people of Lubuk Rukam village, Peninjauan District, OKU Regency refers to the customary concept that comes from the natural philosophy that has been preserved from time to time. It is also can be divided into four parts i.e. 1) The true custom; 2) Customary customs; 3) Customs that are customary; 4) The custom that be customed.

\subsection{Educational Values in Pantun Seserahan in Lubuk Rukam Village, Peninjaun District, OKU Regency.}

The educational values in the pantun seserahan in the village of Lubuk Rukam, Peninjauan District, OKU Regency, can be seen in the following pantun:
Itek putih di atas batang
Perenjak hinggap di ujung ranting
Puas menanti penganten lah datang
Mak ini penganten duduk besanding
Datang tuan, sampai bisan
Serta kaum segale kerabat
Kance sejawat dan handai tolan
Hala lupekan budaya adat

Based on the description of the pantun above, it can be said that it has the meaning of educational values in the village of Lubuk Rukam, Peninjauan District, OKU Regency. In the first verse, the third line is satisfied 
waiting for the bride to come, where all the efforts are made with patient, because the effort will get results.

Furthermore, the educational values in the pantun seserahan in Lubuk Rukam village, Peninjauan District, OKU Regency is found in the second line of the fourth verse, that is Hala lupekan, customary culture which has the meaning of not forgetting customary culture because a custom can educate humans to be able to preserve from generation to generation.

The educational values in the following rhymes in the village of Lubuk Rukam, Peninjauan District, OKU Regency are explained as follows:

\section{Makmane pule padi dek masak \\ Ume pematang bejajar due \\ Makmane dihi dek same anjak \\ Anak suhang jadi hang due}

This pantun has the meaning of educational values which are described in the first line of Makmane pule padi dek masak which means that everything that is done requires a process. Someone who wants to get the achievement is not immediately successful, but it needs continuous learning and practice. Furthermore, the values of education are depicted in the third line of meaning in the same approach as factoring (Makmane dihi dek same anjak or how are we not equally happy) and in the fourth line, Anak suhang jadi hang due or a kid becomes two kids. It means that if we try to do something seriously will reap the expected results. In other words, confidence is the key to success. In the world of trading, the meaning of one kid to be two kids as described in the fourth line showed that if humans are serious in trading, they will get profit.

Another meaning contained in the values of education in the pantun by the people of Lubuk Rukam village, Peninjauan District, OKU Regency is educating humans to create an orderly society and meet security and justice requirements for each member or to create harmony among intellectuals who have different understandings or opinions. Thus, it will bring out the good and eliminate the bad; discard the cloudy and take the clear.

Based on a review of the meaning of educational values in the pantun by the people of Lubuk Rukam village, Peninjauan District, OKU Regency, it can be understood that every human behavior and way of thinking cannot be said to be a value, except after being practiced for a long time and passed down from generation to generation. . There are times when the acceptance of practice is strengthened by legal provisions, so that anyone who violates, especially if it is done deliberately, will be sanctioned. Even though it only relates to the habits or prevalence, the education plays a role in shaping the tradition of educational values. In a simple sense, the educator values are the way humans do things in all aspects of life from the teachings they receive.

\subsection{The More Dominant Values Found in the Pantun Seserahan in Lubuk Rukam Village, Penininjaun District, OKU Regency.}

Based on the description above, it can be explained that the more dominant values contained in the pantun seserahan in Lubuk Rukam Village, Peninjauan District, OKU Regency are cultural values because the culture of the pantun seserahan is still preserved and passed down from generation to generation both by traditional leaders, traditional elders, and members of the community.

As stated by Effendi that pantun has deep meaning of each word with a great arrangement [6]. That's why mostly pantun can not be interpreted based on the surface meaning of the word that is arranged like a sentence. There is a beyond meaning to show how the values exist in that pantun. It means that there is indirect message that is addressed by the poets to the reader or listener.

\section{CONCLUSION}

Based on the facts in Lubuk Rukam village, Peninjauan District, OKU Regency, pantun is still preserved and can see more deeply. Then, based on a review of the meaning of cultural values in pantun by the people of Lubuk Rukam village, Peninjauan District, OKU Regency can interpret that every human behavior and way of thinking cannot be said as culture and tradition, except after being practiced for a long time and derived from creating to create.

Furthermore, the values of education in the pantun seserahan in the village of Lubuk Rukam, Peninjauan District, OKU Regency which are described above, have the meaning of mutual respect between residents. This reflects the behavior of the social life of the community in Lubuk Rukam village, Peninjauan District, OKU Regency. The dominant values contained in the pantun seserahan in Lubuk Rukam village, Peninjauan District, OKU Regency are the cultural values because the culture of the pantun seserahan is still preserved and passed down from creating to generations, both by traditional leaders and traditional elders, as well as the members of the community.

\section{REFERENCES}

[1] Sudjiman. (2013). Mengenal Sastra Indonesia. Jakarta: Rajawali Pers.

[2] Laelasari. (2016). Ikhtisar Kesusastraan Indonesia. Yogyakarta: Adicita.

[3] Sadikin, M. (2010). Kumpulan Sastra Indonesia. Jakarta: Buku Kita.

[4] Nursito. (2000). Ikhtisar Kesusastraan Indonesia. Yogyakarta: Adicita. 
[5] Hutomo, S.S. (2010). Mutiara yang Terlupakan: Pengantar Studi Sastra Lisan. Surabaya: HISKI Jawa Timur.

[6] Effendi. (2013). Tunjuk Ajar Melayu (Butir-Butir Budaya Melayu Riau). Yogyakarta: Balai Kajian dan Pengembangan Budaya Melayu.

[7] Rani, N. (2013). Ilmu Sastra : Teori dan Terapan. Padang: Citra Budaya Indonesia.

[8] Kaswan \& Rita. (2015). Kajian Pantun: UnsurUnsur Budaya Nusantara. Jakarta: Dian Pustaka.

[9] Wardarita, R. (2019). Kajian Bahasa dan Sastra Indonesia. Yogyakarta: Elmatera.

[10] Sugiarto, E. (2012). Pantun dan Puisi Lama
Melayu. Yogyakarta: Khitah Publishing

[11] Alisyahbana. (2014). Kajian Sastra Lama. Yogyakarta: Tiara Wacana.

[12] Prastowo, A. (2011). Penelitian Kualitatif:Teknik Mendesain Pembelajaran. Jogjakarta: Diva Press,

[13] Sukmadinata, N.S. (2011). Metode Penelitian Pendidikan. Bandung: Remaja Rosdakarya.

[14] Endaswara. (2014). Sastra Lisan Koba Rokan Hulu. Pekanbaru: Depdikbud Prov. Riau

[15] Sugiyono. (2015). Metode Penelitian Pendidikan, Pendekatan Kuantitatif, Kualitatif dan R\&D. Bandung: Alfabeta. 